\title{
From Samizdat to New Sincerity. Digital Literature on the Russian-Language Internet
}

\author{
Henrike Schmidt
}

\subsection{Introduction. The Hybrid Nature of Digital Literature}

No clear-cut definition exists to describe digital literature, which is characterized by its hybrid nature and which borders on the fields of information technology, media art, media activism and computer games. Katherine Hayles speaks about "new horizons for the literary," emphasizing that digital literature transgresses a restricted understanding of literature, in the sense of discrete texts and established literary devices (Hayles 2008, 4). Scott Rettberg alternatively uses the term "electronic literature" (2016, 2019; see also Tabbi 2018; O'Sullivan 2019), underlining also its inherent hybridity and the difficulty, if not impossibility, of working with fixed genre definitions. Electronic literature in his view stands at the crossroads of literary practice and critique and is characterized "by the approach rather than content" $(2016,166)$. In the following, digital literature is understood accordingly as an umbrella term for "literary practices in digital and networked environments." Exemplary manifestations of digital literature are animated poetry, text generators producing poems relying on algorithms and hyperfiction, that is, stories told in a digressive, interactive way by using hyperlinks: icons, graphics or text that link to another document or website. For the later phase of increasingly mobile devices, since approximately the early 2010s, one might think of "locative literature" (ibid., 170), in which smartphone apps guide readers through story worlds at real locations,

H. Schmidt $(\triangle)$

Freie Universität Berlin, Berlin, Germany

e-mail: schmidth@zedat.fu-berlin.de 
thus enabling a temporal-physical immersion into the narration. Whether digitized texts, that is, works previously published in print and later converted into digital format, can be classified as digital literature is a topic of debate (Bouchardon 2017, 3). What unites all appearances of literature or "the literary" in the digital sphere is the fact that they are computer-processed and thus rely on code. The literary texts, which the readers perceive on the surface of the computer screen, are secondary, products of the underlying primary text of the computer code. They tend to either hide their computer-generated nature, which we can call media in-transparency, or display it openly, exposing the texts' mediated nature.

Literary practices on the Russian-language Internet (Runet), ranging from online libraries to Facebook life-writing, have become as of 2019 an established theme in Slavic Literary Studies, which analyzes how such phenomena relate to historical developments in Russian literature. Autobiographical blogging may, for example, be researched in connection to Fyodor Dostoevsky's Dnevnik pisatelâ (A Writer's Diary, 1873-1881). These practices constitute an integral part of the broader sphere of Digital Russia Studies, which investigates the interaction between the different segments of culture, politics and economy, for example, the use of literary memes for political campaigning. The newly evolving discipline of Global Russian Studies (Platt 2019) tackles, in turn, questions of transnationally dispersed communities beyond traditional understandings of exile or diaspora, which are important for analyzing Russianlanguage writing-scapes and reading-scapes. Concurrently, digital literature on the Runet is being integrated into the wider context of Global Digital Studies, including literary aspects (Rettberg 2019; O'Sullivan 2019; Tabbi 2018). For some time now, this field has been opening itself up to non-English/non-Latin alphabet based case studies in order to overcome its Western-centricism (Russell and Echchaibi 2009).

Runet literary studies do not differ theoretically or methodologically from global approaches. But they do offer interesting insights into the specific correlations between literary and socio-political evolution in a given national/ cultural context. This is particularly significant for the first phase of Runet development in the early 1990s, when, after the dissolution of the Soviet Union, political transformation and media "revolution" coincided. But it is also relevant to the politicized media environment that has established itself after almost two decades of Vladimir Putin's executive rule as President and Prime Minister. This environment is characterized by a return to vertical power structures, neo-imperialist tendencies and new identity politics (for more on history of Runet, see Chap. 16).

The early manifestations of both Information and Communication Technologies (ICT) and Computer-Mediated Communication (CMC) have been a global inspiration in terms of their potentially democratizing impact, with democratization understood here as access to publication technology, and not primarily in a values sense (Jenkins 2006, 241). Hypertext appeared as the embodiment of a new epistemological system or the realization of long dreamt 
of literary utopias: the ultimate library-non-linear story telling. In global theory on CMC, researchers coined concepts including the "wreader" (George Landow 2006) and "the prosumer" (Jenkins 2006). "Wreaders" co-create meaning in collaborative literary projects; "prosumers" in today's participatory cultures consume and produce at the same time.

Due to the high technical and financial barriers to Internet access in the early phase of Internet development (i.e., from the late 1980s to the mid-1990s), the first users were mostly scientists, programmers at research institutions or academics at universities. As the Internet became more widespread and commoditized, the technically advanced pioneers and "fathers of the Runet" were replaced by a mass of unsophisticated enthusiasts. With each new succeeding generation, the ways in which digital technologies are used are changing, including of course in the field of culture and literature. Editing, copying, sharing and commenting are gradually replacing the creation of "genuine" content. The associated discourses range from the concept of an emancipating collective vernacular creativity, as a continuation of traditional folklore in modern garb, to critical interpretations in the sense of an emerging "prosumer capitalism" (Beck-Pristed 2020, 418). This process is taking place in Russia in analogy to global dynamics. As regards the Runet, such global phenomena and terminology are sometimes embedded into national cultural contexts. A characteristic example of this is the study of amateur creativity, a global phenomenon on the Internet, stimulated by the web's easy-to-use publication technologies (Vadde 2017). In Runet contexts, however, amateur culture tends to be "nationalized," that is, explained with an emphasis on historical or cultural traditions. Both protagonists and researchers contextualize amateur writing with reference to the historical phenomenon of Soviet samizdat literature (Gorny 2006, 197; Kuznecov 2004). Samizdat literally means "self-publishing" (from the Russian "sam" = "self" and izdavat" = "to publish") and relates to a highly elaborated, clandestine publication system of works that were subject to political censorship.

The present chapter continues with a further clarification of terminology. It then offers a survey of the main "genres" of digital literature, ranging from hypertext to blogging. The conclusion outlines main research trends and future desiderata.

\subsection{Literary Practices/Literary Facts on the Runet: Definitions AND Approaches}

Roughly two decades have passed since Computer-Mediated Communication was broadly implemented worldwide. In this period, a complex terminology has been elaborated - and continually deconstructed - that distinguishes (1) digitized from (2) digital and from (3) Internet (networked; seteva $\hat{a}$ ) literature (Bouchardon 2017, 3; Gendolla et al. 2010). According to this approach, digitized literature denotes previously published print texts, digitized to achieve 
broader or different dissemination. A reproduction of a historic poetry collection in one of the numerous online libraries would be a typical example. Digitized literature is differentiated from born digital materials, texts originally written on a computer and which do not have a paper substrate (Hayles 2008, 3). Digital literature, in turn, designates works that rely aesthetically on distinct features of ICT, such as the inclusion of hyperlinks, multimedia or animation. The hyperfiction poem $V$ metro (In the Subway) by Sergey Vlasov and Georgy Zherdev (together with Aleksey Dobkin 2001), offering multiple possibilities to navigate through a set of stories, may serve here as illustration. Internet or networked literature is closely related to digital literature. It also relies naturally on code and is embedded into hyperlinked CMC environments, but its conceptual core is concerned with communication practices (sharing, commenting, liking) and is characterized by the Internet's volatile and often very large communities. An example would be the virtual personae that were popular on the Runet in the late 1990s to early 2000s. A virtual persona is "a fictitious personality, established by a person or group of people which creates semiotic artifacts" (Gorny 2006, 194). Virtual personae, or, respectively, their "authors," use communication forums and websites as a playground for identity games including gender swapping (ibid., 208).

As Scott Rettberg underlines, in electronic or digital literature the individual literary work often is less important than the "exploratory engagement" (2016, 166-167) with contemporary computer technology. Consequently, "toolmaking and platform development" should be considered to be an integral part of it. The latter can be specially generated creative environments. But any existing, even commercial, platforms can also be subjected to poetic uses. On Twitter, for example, literary quotations from an author or on a specific topic can be posted, individually selected or automatically processed relying on algorithmic procedures. Such (semi-)automated forms of poetic meaning production sometimes play with the principle of chance, in a continuation of aleatory avant-garde practices. There exist numerous Twitter accounts of historical and contemporary Russian writers or celebrities - some real, some fictional. Since 2012 , to name but one, the Russian exiled poet and Nobel Prize winner Joseph Brodsky (†1996) has a Twitter account (@brodsky_joseph), which is followed by around 350,000 users. The "authors" standing behind such virtual personae often remain (semi-)anonymous, masked by their pseudonyms. This demonstrates how specific "genres" or usage patterns can migrate from one technical environment like forums or blogs to another (Twitter).

At the same time, since ICT increasingly infiltrates everyday life and routines, including writing and reading, clear-cut distinctions between on and offline become obsolete. Consequently, the concept of a post-digital or postInternet literature has evolved. Post-Internet literature refers to texts that have been produced online but re/turn to paper (Hayles 2008, 159). A typical example would be a blog that is subsequently printed in book form as a kind of sequel, as was the case with the popular online diary written by scriptwriter and novelist Yevgeni Grishkovetz (Izbrannye zapisi, Selected posts, 2014). 
The growing amalgamation of the on and offline spheres poses challenges to fixed definitions. More flexible approaches (re)gain significance, for example, the concept of "remediation." Bolter and Grusin ([1999] 2000) introduced the term in order to describe the multiple processes of media transformation to which any content is subjected. Often labeled "revolutions," these do not, at least in most cases, lead to the extinction of the previous forms but rather to convergence. Concerning the digital sphere, remediations run in opposite directions and on two tracks: from analogue to digital-from print books to digitized manuscripts - and from digital to analogue - from Twitter posts to poetry collections.

Another approach, which relies not on definition but rather on function, revitalizes Russian Formalist theory, particularly in its concepts of "literaturnost" (literariness) and the "literaturnyj fakt" (literary fact) as developed by Viktor Shklovsky and others in the early twentieth century ("Russian Formalism," in Buchanan 2018). "Literariness" is understood as an aesthetic quality (function), which exists not only in literary texts proper but characterizes (online) communication in a broader sense. "Literary facts" are, by contrast, features of non-literary communication (in the present case of digital culture, for example, encodings, media formats or colloquial styles), which in turn affect literary practices.

The chapter follows the typology sketched above, using the concepts of digitized, digital, networked and post-digital literature as a rough grid. In so doing, it avoids normative judgments such as the one arguing that digitized literature, as a "simple" remediation, is less culturally significant than experiments with hypertext or critical explorations of code.

\subsection{The Russian-Language Internet (Runet): Horizontal Versus Vertical Communication Patterns}

The term "Runet" as an object of scientific inquiry is not less elusive than "digital literature." On the global Internet, reading and writing audiences cannot be clearly differentiated according to territorial, national, ethnic or language criteria, despite recent trends toward a re-emerging national sovereignty in the digital sphere (for more, see Chap. 2). This is especially true for Russian contexts, with the existence of a large diaspora and the new "global Russians," constantly moving between their native country and the second homes they have chosen across the world. Grigory Chkhartishvili, also known as Boris Akunin, an author of sophisticated historical detective fiction, is a good example for a global Russian writer: he lives in Europe, in London and Northern France, and continues to influence Russian prose as well as the socio-political discourse via his Facebook account. In this chapter, the term Runet designates the Russian-language Internet accordingly. Where applicable, it will be distinguished from the Internet in the Russian Federation, for example, with regard to the discussion of legislation and regulation. 
In early conceptualizations, the structural horizontality of the Internet was hailed as a technological embodiment of postmodernist concepts, including de-hierarchization and non-linearity (ignoring the fact that the technology was actually developed as part of United States [US] military programs). In the contexts of the Runet, this had two major implications. Firstly, on a philosophical level, media change and the regime change of perestroika seemed to coincide with the metaphor of the horizontal, denoting the non-hierarchical, whether this be realized in political democratization or in digressive narration. Secondly, on a pragmatic level, the abolition of censorship put an end to the hunger for books of the late 1980s, an appetite that was immediately satisfied on the Internet - at least for those who could access it.

The Runet of the early and mid-1990s was a marginal phenomenon, with less than one percent of the Russian population online. The early adopters were either members of the technological elite working at scientific institutions or living abroad, mostly in the US, Israel or Germany. The foremost implication of this was that early literary communication on the Runet took place using the Latin alphabet, as Cyrillic encodings did not yet exist. This new communication environment stimulated linguistic creativity, including the systematic use of obscenities, traditionally named mat. A later offspring of this linguistic inventiveness is the so-called padonki slang (padonki translates as "scumbags"), which relies on the principle of distorted phonetic transcription. Questions of coding thus turned into literary facts. The padonki movement produced, besides an immense corpus of texts that partly can be considered a form of Internet folklore, also its own platform, which was very popular in the $2000 \mathrm{~s}$ (udaff.com; see Goriunova 2012).

The year 1998 put an end to the Runet's marginal status. Paradoxically, this was a consequence of the severe financial crisis, which was accompanied by galloping inflation. The new medium demonstrated that broader user groups could efficiently exploit it, by monitoring ruble exchange rates in real time. Consequently, money and politics entered the scene, and with them "professional" literature. The opening of the Reading Room (Žurnal'nyj zal) in the decisive year of 1998 symbolized and embodied the arrival of established canons and authorities in the digital sphere. The Reading Room represented the tolstye žurnaly (thick journals) and published excerpts or whole issues of renowned journals such as Novyj mir (New World) free of charge. The thick journals have been a peculiarity of Russian reading culture since the late eighteenth century. They publish both literary works and literary criticism and exemplify what is alleged to be Russian literature's exceptional significance, a literature that fulfills not only aesthetic but also ethical and political functions in a public sphere curbed by censorship. As such, they contribute to the essentialist and literature-centric view of Russia as a "reading country." In the perestroika era, their popularity rocketed as they took part in political and social transformation. By the 1990s, however, these journals were ailing, due to an overall tendency of de-canonization and because of the economic problems in disseminating their content to more peripheral regions. Paradoxically, the 
Runet provided a remedy against diminishing circulation and influence while simultaneously representing a diametrically opposed attitude of non-hierarchical literary communication.

With the overall growth of the Internet-jumping from 2 percent of the population in the late 1990s to $40-50$ percent in the 2010 s, and finally catching up in comparison to average global Internet penetration, reaching 76 percent in 2019-state institutions also arrived on the Runet. A legal framework was elaborated for the previously largely unregulated sphere of the Internet within the Russian Federation. Of major significance for literary issues are copyright regulations, implemented in the course of Russia's accession to the World Trading Organization (WTO) in 2012. But legislative measures also include the registration of popular literary blogs under the category of mass media and the blocking of individual works or whole websites for allegedly propagating pornography and pedophilia or "extremism" (for more, see Chap. 5). The ban of the popular instant messenger Telegram in 2018, for example, met with resistance on the part of young users, in particular, and attracted a lot of attention abroad. Experts differentiate between first, second and third generations of Internet control, with the latter embracing repressive methods and so-called positive content, that is, cultural narratives, used to disseminate pro-regime information and values (Deibert et al. 2010, 7). It is writers like the prose author and TV journalist Sergey Minaev who contribute to such content creation in the first place. In his successful novel Media Sapiens. Povest' o tret'em sroke (Media Sapiens. The Story of the Third Term, 2007), Minaev creates an influential picture of oppositional media as manipulated and corrupt. This needs to be contrasted with protest movements against electoral fraud and against vertical power structures since the 2010s. These movements rely massively on online mobilization, and, by so doing, they challenge official Internet policies (for more on digital activism, see Chap. 8). Literary practices on the Runet thus take place in a highly politicized environment. The trope of horizontality, ascribed to the new medium of communication in the postperestroika period, was superseded by the metaphor of the "vertikal' vlasti" (power vertical, Ryazanova-Clarke 2009) as a description of the political system of the Putin era.

\subsection{Literary Practices on the Runet: LibraRies AND LiFe-Writing}

\subsubsection{Digitized Literature: Forming the Canon from Below}

Online libraries figured among the first literary projects of the Runet. Born out of the hunger for books in the post-perestroika era, they made previously censored texts available. These first digital libraries were personal text collections, intended to be shared with like-minded readers. Their initiators belonged to the technical intelligentsia. Typical examples are EEL (Publičnầ èlektronnầ 
biblioteka Evgeniâ Peskina, Eugene's Electronic Library, 1992-1998) and the Moshkov library lib.ru (1994), named after its initiator, the programmer Maksim Moshkov. The latter refused the title of librarian, describing himself instead as a mere "doorman" (Mjør 2014, 217). Readers digitized literary works they wanted to see on the virtual shelves and submitted them for electronic publication. The library reflected an eclectic mix of individual tastes and previously marginalized genres, ranging from religious and esoteric texts to science and cyberfiction writing.

With the arrivals of the "professionals" onto the field of play, academically trained literary critics and philologists, new library projects emerged. The RVB (Russkấ virtual'naâ biblioteka, Russian Virtual Library, 1999) offered literary works in accordance with academic standards while modifying the canon by including samizdat poetry. The FÈB (Fundamental'naâ èlektronnaâ biblioteka 'Russkaâ literatura ifol'klor', Fundamental Digital Library of Russian Literature and Folklore) was the first online library partly financed by state money and affiliated to pre-digital academic institutions, in this case the Gorky Institute of World Literature. The FĖB reproduced the literary canon of pre-revolutionary Russia in authoritative digital editions, partly relying on Soviet scholarship and thus implicitly its norms (Mjør 2014, 223).

All libraries provided popular communication forums and metamorphosed from text repositories into social networks in their own rights. For the Runet as a global reading-scape, embracing remote Russian regions and the global diaspora, the online libraries represented a much-needed source of information. At the same time, through their functioning as social networks, they turned into "source[s] of identification" (Mjør 2014, 219). In addition to the troika of the renowned Runet libraries, there exists a multiplicity of smaller, less conceptual, but not less popular, online libraries, where books-especially contemporary prose - can be downloaded for free, in part still illegally. Peter Shillingsburg has called such amateur libraries the "dank cellar" of the Internet, worth consideration as an expression of canon formation from below (Shillingsburg 2006, 138).

An abrupt change in the history of these book repositories occurred in 2004, when the Moshkov library was sued for copyright violations. As a reaction to the trial, the "readers' librarian" changed his publication policies. New entries in the library were restricted to texts available in the public domain. In addition, Moshkov initiated a platform associated to the library where authors can publish their texts themselves. Named Samizdat, the nomenclature refers to discourses about the Runet as an extension of unofficial Soviet publication practices, as detailed above.

A decade later, in 2014, the first large-scale state-financed digital library project was initiated: NÈB (Nacional'naâ èlektronnaâ biblioteka, National Electronic Library). The NÈB unites the digital collections of a multiplicity of Russian libraries. It is oriented toward the professional reader. Contemporary fiction protected by copyright is not publicly available but can be accessed from the electronically equipped reading rooms of participating institutions. 
Thus, 2004 was a watershed year, marked by the Moshkov trial and the gradual implementation of regulations covering authorial rights. Alongside this, a commercial sector for literary content evolved. This process was stimulated technologically, by the availability of mobile devices-including smartphones, tablets and e-book readers-and specific e-book formats-epub, $\mathrm{fb} 2$-which detached reading from stationary computers. Only one year later, the Litres.ru e-book store, originally a network of smaller online libraries, started its activities on a pay-per-download basis. In the years following it established itself as market leader, actively opposing "pirated" resources. Other providers of legal literary content followed, offering different distribution systems. In 2007, Kroogi (Circles), a sharing platform for music, art and literature, went online, based on a pay-what-you-want strategy. Kroogi also offers crowdfunding models. A little later, in 2010, Bookmate was founded as a Freemium service. Users pay a monthly fee to access copyrighted content, which consisted of roughly 800,000 literary texts and audio books as of 2018 . In order to structure the abounding wealth of content and to work with their audiences, all of the named e-book services provide multiple communication forums and incentive systems. They arrange editors' and readers' recommendations, rankings and awards, incorporating functions that were previously distributed among different institutions (online libraries, magazines, awards).

As a result, a functioning e-book market has emerged, accounting in 2018 for five to seven percent of the book market as a whole (Federal'noe agentstvo 2018, 57): compare with thirty percent in the US. Pay-per-download, subscription and sharing models co-exist. Nevertheless, as of 2018, about half of all e-books were being downloaded illegally using torrents and social networks or being read free of charge from online libraries (Anuryev n.d., 6). Among electronic bestsellers, genre fiction dominates: romantic fiction, detective novels and sci-fi. A significant tendency is the growing popularity of audio books. A more crucial trend still is the dynamically evolving segment of self-publishing, similar to the development in the US, where, as of the late 2010s, one-third of all e-books are indie productions. The company Rideró is the market leader in the field of self-publishing in Russia. But all of the big players in the field of legal e-book content offer self-publishing services. LitRes characteristically named it Samizdat, referring-as Moshkov had done before it- to the Soviet reading and publishing tradition discussed above but stripping the term of any political significance.

A noteworthy number of Russian authors agree to flexible publication models, which combine free access for on-screen reading with payment models for downloads, for example, Internet-savvy writers like Viktor Pelevin or Boris Akunin. Genres that have no market value are broadly accessible on the Runet. The main trends in contemporary poetry are represented free of charge on websites and journals such as Vavilon, Text Only, and Novaâ kamera braneniâ (New Storage Room). 


\subsubsection{Hypertext Digressions and Media Criticism}

In their nascent phases, the Internet in general — and hypertext in particularstirred multiple utopian visions. For literature proper, these were dreams of the ideal library or the emancipation of narration from the yoke of linearity, inspired by the short stories Library of Babel (1941) and The Garden of Forking Paths (1941), by Argentinian writer Jorge Luis Borges. The Runet's literary pioneers also soon explored hypertext as a possibility for new writing modes, for example, in the collective poetry project Sad rashodôsibsa hokku (The Garden of Forking Haiku, 1997; Roman Leibov/Dmitry Manin), paying homage to Borges as the global icon of pre-hypertext digressive narration. They were well acquainted, too, with the hypertext experiments in what was, at the time, the dominant player in digital literature: texts by American authors, including Michael Joyce's afternoon, a story (1987).

While the utopia of the Internet as a library was realized spontaneously, fueled by the late Soviet hunger for books, hyperfiction remained restricted to a small number of experiments. These Russian explorations of hyperfiction often critically reflected on rampant hypertext euphoria. Thus, media artist Alexei Shulgin in his manifesto Art, Power and Communication (1996) dismantled hyperlinking as a simulation of interactivity, while behind the screens the author held even more subtle powers than previously for manipulating readers (for more, see Chap. 14). Another such epistemological critique of hypertext is articulated in the cyberfiction of postmodernist writer Pelevin, the chronicler of digital culture in Russia, for example, in his short stories Princ Gosplana (Prince of Central Planning, 1992) or Akiko (2003). Skepticism about hypertext is partly motivated by (auto)biographical experiences of the advanced manipulative techniques of Soviet totalitarianism.

Iconic works of hyperfiction are Roman Leibov co-authorship of Roman, which would translate into English as Novel, though no English translation has been published to date (1995-1996; programmer Dmitrij Manin), and Olia Lialina's My Boyfriend Came Back from the War (1996; for more, see Chap. 14). Leibov Roman is a conceptual experiment with the im/possibilities of turning readers into co/writers. The title has a trifold meaning, denoting the genre (novel), the style (romance) and the first name of its author, including an allusion to the Roman alphabet, in which the text was written, due to the lack of Cyrillic web encodings at the time. Its core consists of a short text fragment, a juvenile love story with an open end. Readers were invited to send in alternative versions. A dozen author-readers produced around two hundred pages of text. After a year of organic growth, the text became unreadable and Leibov stopped the experiment, which from the beginning was intended as a philological critique of hypertext theory.

An immersive version of a multimedia, animated hypertext is presented by the creative collective consisting of Sergey Vlasov (text), Georgy Zherdev (concept/animation) and Aleksey Dobkin (photography). V metro (In the Subway) organizes its fragmentary text as a Moscow metro map, with readers 
"entering" and "leaving" it with the help of hyperlinks. Media theoretician Roberto Simanowski describes such creative cooperation among authors, artists and programmers as a new "artes mechanicae" (Simanowski 2002, 148).

Runet hyperfiction is of interest today for reasons of literary history rather than formal innovation. The tireless innovator Akunin continues to experiment with digressive narration, for example, in his novel Kvest (Quest, 2009), designed as a game and supplemented by its own interactive website. Animation and code work in the sense of aesthetic explorations of computer code are less frequent still. An example of critical work with code is Aleksroma's digitized version of the novel Idiot (The Idiot, 1868), by Fyodor Dostoevsky, rearranged as a news ticker (2001). "Reading" the text would take 24 hours and is intentionally inconvenient. Aleksroma's animated version of The Idiot underlines how disrespectful remediation can flash out the specific gains and losses that a text can be effected by, in its transfer from analogue to digital format. It thus functions as a multimedia critique of euphoria about technology.

\subsubsection{Bottom-Up Creativity: Amateur Literature, Fan Fiction, kreatiff}

While hypertext and the concept of the "wreader" were soon criticized as simulating rather than stimulating interactivity (Simanowski 2002, 66-68), amateur literature and fan fiction blossomed worldwide. "Amateur" is not a clearly definable term in literary theory. Instead, it should be viewed as one part of the cultural battles between "professionals" and "dilettantes" (Vadde 2017). The potentially democratizing effects of easy to use digital publication technologies provoke a redistribution of symbolical capital between established institutions, which act as gatekeepers, and newcomers. Practices and discourses on the Runet do not differ much from similar dynamics on a global scale, although two areas of divergence are worthy of discussion. Firstly, the terrain of Russian literature has traditionally been characterized by a strong orientation around canon and authority, a result of the long periods of strong state interference into culture. On the one hand, this intensifies the quarrels between "amateurs" and "professionals." On the other, amateur culture is not by default critical visà-vis the canon but rather reproduces it by (re)cycling its "masterpieces." Secondly, self-publishing is terminologically and historically linked to the phenomenon of Soviet samizdat, as elaborated earlier. However, literary critic Dmitry Kuz'min (1999) stresses instead the differences between a politically motivated samizdat of the Soviet type and today's media-stimulated selfpublishing activities: the existence of an informal but strong quality control in the former.

Since 2000, the largest self-publishing portals on the Runet have been the twin portals stihi.ru for poetry and proza.ru for prose genres. Hundreds of thousands of authors have published literally millions of texts on both portals. Publication on these privately initiated platforms is free of charge. These immense text repositories are structured with the help of editors' and readers' 
recommendations. Stihi.ru and proza.ru regularly organize literary awards in order to motivate and promote their authors. Some, such as the Heritage Award (Nasledie), express a patriotic agenda. Texts published on stihi.ru and proza.ru adhere to the category of born digitals, in having no paper substrate and in not being primarily intended for print publication. But these platforms, as with most semi-professional content providers, also offer self-publishing as print on demand, for a small charge. This illustrates the tendency of digital literature to move into a post-Internet sphere. Self-publishing reveals itself to be a lucrative market.

Fan fiction, in comparison to amateur literature, is closely tied to the narrative worlds of novels or film sagas such as The Lord of the Rings (1937-1949) by J.R.R. Tolkien or the Harry Potter saga by J.K. Rowling (1997-2007). Media theoreticians such as Marie-Laure Ryan and Thon (2014) attribute higher immersive potential to fan fiction than they do to hyperfiction. In fan fiction, the reader turns into a writer herself-fan fiction writers are mostly women - and is able to expand or change the narrative. Amateur and fan fiction have generated commercially very successful authors, including E.L. James (Erika Leonard) with her erotic novel sequence Fifty Shades of Grey (2011-2017). Disregarding these economic success stories, the majority of its adepts perceive amateur and fan fiction as a basically non-commercial activity, the last realm of "pure" creativity. Fan fiction, as amateur literature, represents the born digital text type. While the technology to print it does of course exist, both protagonists and researchers often perceive it as not transferable to paper, due to its high embeddedness in the specific communication environments (Samutina 2017).

Russian fan fiction, at ficbook.net, for example, does not differ structurally from analogous writing worldwide. Harry Potter fiction, to name just one of the most popular fan fiction universes globally, also has its share of Russian users (ibid.). It is generally fantasy and sci-fi with their complex story worlds that generate the most impressive amounts of fan fiction. Thus, the narrative universe of the Strugatsky Brothers (Arkady and Boris), who dominated the genre in the late Soviet era, stimulate a lot of Russian fan fiction, as do contemporary sci-fi and cyberfiction writers like Dmitry Glukhovsky (Metro series, 2002-2015) or Sergey Lukyanenko (Dozory/The Watchsequence, 1998-2018), both of whom started as indie or fan fiction writers.

Further phenomena relating to participatory culture are Internet memes and "netlore"-Internet folklore. The term "meme" developed out of Richard Dawkins' contested theories of cultural evolution and describes micronarratives that spread across media. Memes typically include not only linguistic or literary components but also visual ones. In contrast to amateur or fan fiction, memes are often created anonymously, moving them closer to the pole of folklore production. In Russian contexts, they are sometimes associated with lubok, popular prints that circulated in pre-revolutionary Russia.

Moreover, the new concept of kreatiff appeared on the Runet in the 2000s, designating non-commercial cultural creation that is located in the intersection 
between amateur fiction, fan fiction and netlore. The term is a linguistic distortion of the English word "creative." The most popular kreatiff has been the Preved-Medved meme. Its narrative core consists of an erotic scene, with a bear (in Russian: medved') surprising a couple having sex in the woods by saying "hello" to them (in Russian: privet). The picture is taken from the US artist John Lurie and its English text is "translated" into padonki. At the time the meme was created, the bear motif referred implicitly as well to President Dmitry Medvedev. The meme combines allusions to traditional Russian folklore (the bear motif in fairy tales), counter-cultural linguistic creativity and political humor. Both padonki jargon and the Preved-Medved meme function as literary facts in the Russian formalist sense: they both influence literary writing. Thus, postmodernist writer Pelevin titled his chat-novel Šlem užasa. Kreatiffo Tesee $i$ Minotavre (The Helmet of Horror: The Myth of Theseus and the Minotaur, 2005), a kreatiff.

\subsubsection{Blogging: Non-literariness and New Sincerity}

Around the year 2000, global Internet culture witnessed the paradigm shift from web 1.0 to web 2.0. This shift was characterized by a move from individual homepages to standardized blogging and social media platforms. On the Runet, writers' homepages as the central location, where the author's persona was constructed, became outdated. Previously, this is where Akunin had played his games of self-mystification, related to the hero of his series of historical mystery novels, Fandorin (1998-2018). Pelevin hid as much behind his fan community as he did behind his trademark sunglasses. The queen of crime fiction, Aleksandra Marinina, invited readers to virtually and visually inspect her writing desk. But such self-staging always remained embedded in these authors' respective narrative text-worlds. The communication format of the blog, by way of contrast, with the timeline as the main organizational principle, pulled the author back to the front of the stage, after their role had been marginalized by hypertext theory. Writing on the Internet became increasingly autobiographical.

Blogging was one of the most popular forms of online activity on the Runet from 2002 until 2017. The beginning is clearly marked by a typesetting blog entry by Leibov, who had already "invented" Russian hyperfiction. This triggered a blogging boom. A significant number of Russian authors engaged in intensive blogging, in close interaction with their geographically dispersed readership: Akunin, a literary Internet explorer in all senses of the word; Grishkovetz, playwright and author of neo-sentimental prose; Lukyanenko, prominent sci-fi and cyberfiction writer; and Tatyana Tolstaya, author of sophisticated post-mythological prose. But blogging also offered possibilities to previously less known writers. These included the prolific essayist Linor Goralik (snorapp) or the poetry performer Vera Polozkova (vero4ka). While the early era of literary activities on the Runet had been predominantly malewith the exception of renowned figures such as media artist Lialina-women 
writers have caught up since the 2000s. Polozkova has published her blog poetry in book format (Nepoèmanie, an untranslatable neologism playing with the Russian word for "misunderstanding," 2008) and produces carefully staged poetry clips. Her example illustrates the tendency toward post-Internet literature, with digital literature reverting to paper and, at the same time, a trend to a remediated orality.

Participant and observer Yevgeni Gorny portrays the Russian blogosphere as a playground for virtual identities (Gorny 2006). Literary scholar Ellen Rutten takes a different standpoint, highlighting the seemingly paradoxical fact that Russian writers are attracted by blogging specifically because it is perceived as a non-literary activity (Rutten 2017). From this perspective, it is precisely the quality of the blog as an informal communication channel, again, a literary fact in the Russian formalist sense, which has enabled non-polished, everyday language to refresh literary communication. Russian literary blogging stands symptomatically for a broader tendency, moving from postmodernist irony toward "new sincerity" (ibid.)

Runet blogging is characterized by the peculiarity that it was closely linked to one specific blog provider: the US-based LiveJournal.com (LJ). The brand name was even translated into Russian as Živoj Žurnal, meaning "the lively journal." Blog researcher Gorny relies on cultural psychology to explain this: LJ nurtured the integration of individual blogs into a wider community by offering specific technological features. This process chimed with the allegedly collectivist psychology of Russian society (Gorny 2006, 253). Others contextualize this development in political terms (Howanitz 2020, 4-5): the strong emergence of blogging coincided with a wave of control of the Runet. The fact that LJ servers were based physically in the US was experienced as a protection from surveillance at home. The end of the LJ era was directly linked to these issues. In 2017, LJ moved its servers to Russian Federation territory to comply with Russian data location laws (for more, see Chap. 5). Parallel to this, the company changed its terms and conditions, prohibiting "political agitation." Bloggers interpreted this as kowtow before Russian authorities. Prominent authors deleted their Živoj Žurnal accounts en masse.

\subsubsection{Social Networks: Life-Writing, Public Expression and "Prosumer Capitalism"}

For the social network services (SNS) in a narrower sense, the Internet in Russia shows peculiarities comparable to those evident in Runet blogging. Besides Facebook as the globally dominant actor, local social media platforms have grown up: Odnoklassniki ("Classmates," founded 2006) and VKontakte, which is known and branded as VK ("In Contact," also founded 2006). The latter has since then outmatched both its local as well as its US-based competitors. A multiplicity of literary activities thrive on VKontakte, from reading clubs to Russian authors connecting directly with their audiences. VK is also 
used to circulate creative content, often still illegally, and enforces authorial rights regulations less rigorously than its global competitors.

Although smaller in terms of user numbers in Russia, the social media giant Facebook is especially popular among writers and public intellectuals. It was the exodus from LiveJournal that led authors to Facebook in the first place: Tolstaya (206,000 followers) and Akunin (250,000 followers) are among the most prominent to date. Social media profiles of Russian authors, be they on VKontakte or on Facebook, intensify the trend toward autobiographical or lifewriting. Writers stage their author personalities in direct interaction with the audiences (autoheterobiography; Lüdeker 2012, 147). Strategies are diverse. Tolstaya presents herself as a private person, mixing personal photographs with invitations to her readings. Akunin retains elements of self-mystifying identity play. His username is a combination of pseudonym and surname, Akunin Chkhartishvili. He uses Facebook as an efficient channel to promote his work in cooperation with e-book stores. Concurrently, he continues to participate in political debate, representing the Putin-critical wing among the Russian intelligentsia. At the other end of the political spectrum stands the prominent patriotic writer Zakhar Prilepin (98,000 followers). Prilepin, who rose to fame through his novel about the Chechen War (Patologii, The Pathologies, 2005), comments on literary culture in contemporary Russia but also reports from the armed conflict between the Ukraine and Donbass secessionists, who are supported by Russia.

Hence, not only do social media profiles by Russian writers function as autobiographical life-writing, they are also part of the composition of the Runet as a deformed but effective public sphere in an otherwise tightly controlled media landscape. They exemplify the formation of global reading-scapes, which are united by language and partly shared collective experience but are also undermined by new ethnic, cultural, national or political affiliations.

In addition to Facebook and its Russian analogues, SNS encompass a variety of other platforms, each of which is characterized by distinct features, operating as literary facts and fostering specific literary usages. Twitter has been used for political mobilization, but the brevity of its messages also promotes the emergence of poetic miniatures. Despite this fact, Russian-language Twitter and Instagram poetry have yet to produce literary celebrities comparable to Indian-born Canadian poet Rupi Kaur. Instant messaging apps are also used for literary purposes. Despite the blocking of the aforementioned popular messenger Telegram, numerous literary channels are active there. As with other SNS, the forms of use are wide ranging. Professional translators or publishers offer glimpses into their work, and addicted readers give personal book recommendations. The "Chekhov writes" channel (@chekhovpishet, initiated by Yevgeni Pekach, about 16,000 subscribers), on the other hand, is an example of projects that closely integrate literature into the lives of readers. Subscribers regularly receive (historical) letters from the famous innovator of Russian prose from the beginning of the twentieth century, Anton Chekhov, via their Telegram account. In contrast to "locative literature," there is not a spatial but 
a temporal immersion. Historical and contemporary reading contexts are fused and contrasted. For the future, Pekach and the editorial team plan to use bots, software applications that execute automatic tasks, to process Chekhov's letters according to search keywords. The final vision is the creation of a virtual "Anton Chekhov" dialogue partner relying on artificial intelligence technology. On YouTube, and its local equivalent Rutube, spoken-word artists and poets circulate recordings of poetry readings or produce poetry clips, fostering a newly mediated orality. One especially popular example of this was occasional poetry by writer and journalist Dmitry Bykov in the early 2010s, who fittingly named his literary project Citizen Poet (an allusion to Nikolay Nekrasov's famous political poem "Poèt i graždanin," The Poet and the Citizen, 1856). In a serialized form, Bykov commented on daily politics in traditionally rhymed verses, which were performed by renowned actor Mikhail Yefremov (producer: Andrey Vasilyev).

SNS are not restricted to life-writing, literary experiments and political communication by writers proper but have also stimulated the emergence of huge reading communities (Livelib.ru being the Russian equivalent to Amazon's Goodreads). Brigitte Beck-Pristed presents a case study of such "social reading," understood as "sharing reading experiences through user-generated book comments, reviews, readers' rankings and recommendations" (Beck-Pristed $2020,407)$. She shows how reading in digital environments is returned to its "haptic, bodily experience" by being staged as a sporting challenge (reading marathon) on the one hand and as individual quality time on the other. Photographs of the "good old paper books" are posted on the social reading platforms, which show readers relaxing lazily with a steaming teacup in their hands (420-422). These reading networks have market power and popularize authors beyond the established institutions of literary criticism (Vadde 2017). From a more critical point of view, readers are doubly exploited in terms of "prosumer capitalism," stresses Beck-Pristed (2020): they produce unpaid content and are the object of targeted advertising.

\subsection{Fields of Research: Toward Mixed Methods}

Runet literary studies rely on terminology and concepts developed in global Internet theory-remediation, convergence, participatory culture, transmedia story telling-but also incorporate approaches from Russian Formalism, including the notions of non-/literariness and the literary fact. Especially in the Runet's early years, the mid-1990s, researchers made sense of the new medium by embedding it into local reading traditions (the samizdat narrative). Such cultural "domestications" of the new global medium were partly essentializing, ascribing to it seemingly inherent characteristics of Russian culture (literaturecentrism and collectivism). There is a strong tendency to personalize the (literary) history of the Runet by focusing on pioneering protagonists (Gorny 2006). Given the especially high percentage of male forerunners, feminist narratives of developments have only recently begun to appear (Ratilainen et al. 
2019). The same is true for studies that focus on the significance of digital literature for the regions and ethnic minorities. More attention has been paid to transnational Russian-language reading-scapes (Stahl 2018). Dirk Uffelmann (2014) discusses aspects of Russian cyber-imperialism, with Russian being the lingua franca for users in ex-Soviet countries. Rutten et al. (2013) focus on "web wars" concerning disputed events of twentieth century and contemporary history, which are fueled by and feed into literary narratives. Complementary to such large-scale approaches, a multiplicity of specialized studies exist, which focus on protagonists (Gorny 2006), institutions (Mjør 2014), genres (Coati 2012; Schmidt 2014) and discourses (Rutten 2017).

Concerning methodology, qualitative approaches, including hermeneutic or formalist readings (literary devices, genres patterns), have the upper hand. Quantitative approaches are applied in Digital Humanities and Russian and East European Studies (DHREES) at Yale University (Marijeta Bozovic) and the Digital Humanities in the Slavic Field research association. Natalia Samutina (2017) in her analysis of Russian fan fiction employs long-term participant observation. First exemplary case studies use quantitative methods (topic modeling, literary network analysis; Howanitz 2020). Challenges for future research lie: in combining quantitative and qualitative research (mixed methods); in documentation and archivation; in feminist renderings of Runet literature; in case studies of translocal and transnational Russian-language reading-scapes; and in a further integration into the discipline of Global Russian Studies, highlighting similarities as well as autonomous developments while avoiding essentialization and exoticization.

\subsection{Conclusions: Content Outplays Code}

Literary practices on the Russian-language Internet are, as we would expect, a phenomenon of "glocalization." The term is a portmanteau of globalization and localization, introduced in the 1990s by renowned sociologists such as Roland Robertson and Zygmunt Bauman, in order to describe overlapping global and local dynamics in an increasingly networked world. With the evergrowing popularity of worldwide SNS and the dominance of global Internet companies such as Amazon and Google, which influence the literary field with game-changing publication and digitization technology, the Runet integrates structurally and functionally more closely into global reading cultures and trends as "New Sincerity" (Rutten 2017). That said, and while the dynamics on the Russian e-book market in the late 2010s are comparable to those in the US (while starting from a lower total level of sales), its local market leaders like LitRes or Rideró outsell Amazon. The appropriation of LiveJournal for specifically Russian-language blogging needs also illustrates how global Internet brands can become "localized."

Supposedly specific features of Runet literature are located on the level of cultural discourse - for example, self-publishing as samizdat - rather than on the level of the textual artifacts themselves. But Runet literary studies show that 
genre patterns may differ as regards socio-political dynamics. Thus, content creation was partly more influential than coding experiments, in contrast to what Scott Rettberg states in his approach to electronic literature $(2016,166)$. This does not mean that content and code (form) should be seen as unrelated but that code is perceived as "transparent" (neutral in terms of meaning) by both the authors and the readers. Such content orientation on the Runet is a consequence of the pronounced needs to communicate that a literature in transition contained. The early Runet filled the gaps in the post-perestroika literary infrastructure and generated textual riches, which amaze readers until today. Against the background of Russian official culture's strongly normative orientation, and in light of new identity politics, the digital arena continuously renegotiates norms (Lunde and Paulsen 2009). The remarkable activity of renowned writers on the Runet therefore is less a consequence of the persistent myth of Russian "literature-centrism" and rather more the result of highly politicized reading environments. Cultural change is often generated outside the literary field in the narrow sense, overlapping with net art, media activism, computer games or linguistic evolution, for example, padonki slang.

The outlined overview of literary practices on the Russian-language Internet shows that digital literature in the narrower sense, from hypertext to code experiments, and changes in literary communication due to alternative distribution channels of digitized literature are closely intertwined. The case of the Runet encourages rethinking overly rigid definitions of digital or electronic literature (Gendolla et al. 2010; Rettberg 2016; see O'Sullivan 2019, 26-38), which tend to exclude digitized texts or post-Internet literature.

\section{REFERENCES}

Aleksroma [Aleksandr Romadanov]. 2001. F. Dostoevsky, Idiot. Setevaâ slovesnost' [Web Literature], May 4. http://www.litera.ru/slova/alexroma/idiot.htm. Copy in Internet Archive. http://web.archive.org/web/20040123170327/http:// www.russianwriter.com/flash/idiot/idiot.swf.

Anuryev, Sergey. n.d. Rynok èlektronnyh knig. Tendencii razvitiâ i predvaritel'nye rezul'taty 2017 goda [The e-book Market. Trends in Development and Preliminary Results]. Accessed January 9, 2019. https://bookunion.ru/upload/iblock/f83/ f833d535c0995e199fb6206c056d03eb.pdf.

Beck-Pristed, Brigitte. 2020. Social Reading in Contemporary Russia. In Reading Russia. A History of Reading in Modern Russia, ed. Damiano Rebecchini and Raffaella Vassena, vol. 3, 407-432. Milano: Ledizioni.

Bolter, Jay David, and Richard Grusin. [1999] 2000. Remediation: Understanding New Media. 3. print. Cambridge, MA: MIT Press.

Bouchardon, Serge. 2017. Towards a Tension-Based Definition of Digital Literature. Journal of Creative Writing Studies 2 (1), article 6: 1-13. https://scholarworks.rit. $\mathrm{edu} / \mathrm{jcws} / \mathrm{vol} 2 / \mathrm{iss} 1 / 6$.

Buchanan, Ian. 2018. Russian Formalism. In A Dictionary of Critical Theory, ed. Ian Buchanan. Oxford: Oxford University Press. Current Online Version. https://doi. org/10.1093/acref/9780198794790.001.0001. 
Coati, Elisa. 2012. Russian Readers and Writers in the Twenty-First Century: The Internet as a Meeting Point. PhD diss., The University of Manchester. ProQuest Dissertations Publishing. http://search.proquest.com/docview/1774233751/ ?pq-origsite $=$ primo.

Deibert, Rafal, John Palfrey, Rafal Rohozinski, and Jonathan Zittrain, eds. 2010. Access Controlled: The Shaping of Power, Rights, and Rule in Cyberspace. Cambridge, MA: Cambridge University Press.

Federal'noe agentstvo 2018 = Federal'noe agentstvo po pecati i massovym kommunikaciâm [Federal Agency on Media and Mass Communications]. 2018. Knižnyj rynok Rossii. Sostoânie, tendencii i perspektivy razvitiâ v 2017 godu [The Russian Book Market. Status, Tendencies and Outlooks for the Year 2017]. Moscow. http:// www.fapmc.ru/rospechat/activities/reports/2018/pechat2.html.

Gendolla, Peter, Jörgen Schäfer, and Roberto Simanowski, eds. 2010. Reading Moving Letters: Digital Literature in Research and Teaching. A Handbook. Bielefeld: transcript Verlag. https://doi.org/10.14361/9783839411308.

Goriunova, Olga. 2012. Art Platforms and Cultural Production on the Internet. London: Routledge.

Gorny, Eugene. 2006. A Creative History of the Russian Internet. PhD diss., Goldsmiths College, University of London. http://citeseerx.ist.psu.edu/viewdoc/download?d oi $=10.1 .1 .132 .1099 \& \mathrm{rep}=\mathrm{rep} 1 \&$ type $=$ pdf.

Hayles, Katherine. 2008. Electronic Literature: New Horizons for the Literary. Notre Dame: University of Notre Dame Press.

Howanitz, Gernot. 2020. Leben weben: (auto-)biographische Praktiken russischer Autorinnen und Autoren im Internet [Weaving Life: (Auto)biographical Practices of Russian Authors on the Internet]. Bielefeld: transcript. https://doi. org/10.14361/9783839451328.

Jenkins, Henry. 2006. Convergence Culture: Where Old and New Media Collide. New York: New York University Press.

Kuz'min, Dmitry. 1999. Kratkij katehizis russkogo literaturnogo Interneta [A Short Catechism of the Russian Literary Internet]. Inostrannaâ literatura [Foreign Literature] 10. Cited from Setevaâ slovesnost' [Web Literature]. Accessed February 22, 2019. https://www.netslova.ru/kuzmin/kuzm-inlit.html.

Kuznecov, Sergej. 2004. Ošupyvaâ slona (Zametki po istorii russkogo Interneta) [The Elephant in the Dark (Notes on the History of the Russian Internet)]. Moscow: Novoe literaturnoe obozrenie.

Landow, George. 2006. Hypertext 3.0: Critical Theory and New Media in an Era of Globalization. 3rd ed. Baltimore: Johns Hopkins University Press.

Leibov, Roman, and Dmitry Manin. 1995-1996. Roman [Novel]. http://www.cs.ut. ee/ roman_l/hyperfiction/.

Lüdeker, Gerhard. 2012. Identität als Selbstverwirklichungsprogramm: Zu den autobiografischen Konstruktionen auf Facebook [Identity as Self-realization: Autobiographical Constructions on Facebook]. In Narrative Genres im Internet: theoretische Bezugsrabmen, Mediengattungstypologie und Funktionen [Narrative Genres on the Internet: Theoretical Framework, Typology of Media Genres and Functions], ed. Ansgar Nünning, Jan Rupp, Rebecca Hagelmoser, and Jonas-Ivo Meyer. Trier: WVT.

Lunde, Ingunn, and Martin Paulsen, eds. 2009. From Poets to Padonki: Linguistic Authority and Norm Negotiation in Modern Russian Culture. Bergen: University of Bergen. 
Mjør, Kåre Johan. 2014. Digitizing Everything? Online Libraries on the Runet. In Digital Russia: The Language, Culture, and Politics of New Media Communication, ed. Michael S. Gorham, Ingunn Lunde, and Martin Paulsen, 215-230. London: Routledge.

O'Sullivan, James. 2019. Towards a Digital Poetics: Electronic Literature \& Literary Games. Cham: Springer International Publishing. https://doi. org/10.1007/978-3-030-11310-0.

Platt, Kevin M.F., ed. 2019. Global Russian Cultures. Madison: University of Wisconsin Press.

Ratilainen, Sara, Mariëlle Wijermars, and Justin Wilmes, eds. 2019. Re-framing Women and Technology in Global Digital Spaces. Digital Icons. Studies in Russian, Eurasian and Central European New Media 19: i-iii. https://www.digitalicons.org/issue19/ editorial-issue-19.

Rettberg, Scott. 2016. Electronic Literature as Digital Humanities. In A New Companion to Digital Humanities, ed. Susan Schreibman, Raymond George Siemens, and John Unsworth, 127-136. Chichester: Wiley-Blackwell.

. 2019. Electronic Literature. Cambridge: Polity.

Russell, Adrienne, and Nabil Echchaibi, eds. 2009. International Blogging: Identity, Politics and Networked Publics. New York: Lang.

Rutten, Ellen. 2017. Sincerity after Communism: A Cultural History. New Haven and London: Yale University Press.

Rutten, Ellen, Julie Fedor, and Vera Zvereva, eds. 2013. Memory, Conflict and New Media: Web Wars in Post-socialist States. London: Routledge.

Ryan, Marie-Laure, and Jan-Noël Thon, eds. 2014. Storyworlds across Media: Toward a Media-Conscious Narratology. Lincoln: University of Nebraska Press.

Ryazanova-Clarke, Lara. 2009. How Upright Is the Vertical? Ideological Norm Negotiation in Russian Media Discourse. In From Poets to Padonki: Linguistic Authority and Norm Negotiation in Modern Russian Culture, ed. Ingunn Lunde and Martin Paulsen, 288-314. Bergen: University of Bergen.

Samutina, Natalia. 2017. Emotional Landscapes of Reading: Fan Fiction in the Context of Contemporary Reading Practices. International Journal of Cultural Studies 20 (3): 253-269. https://doi.org/10.1177/1367877916628238.

Schmidt, Henrike. 2014. Russian Literature on the Internet: From Hypertext to Fairy Tale. In Digital Russia: The Language, Culture, and Politics of New Media Communication, ed. Michael Gorham, Ingunn Lunde, and Martin Paulsen, 177-193. London: Routledge.

Shillingsburg, Peter. 2006. From Gutenberg to Google: Electronic Representations of Literary Texts. Cambridge: Cambridge University Press.

Shulgin, Alexei. 1996. Art, Power, and Communication. nettime, October 7. https:// www.nettime.org/Lists-Archives/nettime-1-9610/msg00036.html.

Simanowski, Roberto. 2002. Interfictions. Vom Schreiben im Netz [Interfictions. On Web Writing]. Frankfurt a.M.: Suhrkamp.

Stahl, Henrieke. 2018. Subject and Space in Political Viral Poetry Concerning the Russia-Ukraine-Crisis. In People and Cultures in Motion: Environment, Space, Subject and Humanities. Proceedings of an Interdisciplinary Conference, ed. Ralf Hertel and Christian Soffel, 89-96. Taipei: Chengda University Press.

Tabbi, Joseph, ed. 2018. The Bloomsbury Handbook of Electronic Literature. London et al.: Bloomsbury. 
Uffelmann, Dirk. 2014. Is There a Russian Cyber Empire? In Digital Russia: The Language, Culture, and Politics of New Media Communication, ed. Michael Gorham, Ingunn Lunde, and Martin Paulsen, 266-284. London: Routledge.

Vadde, Aarthi. 2017. Amateur Creativity: Contemporary Literature and the Digital Publishing Scene. New Literary History 48 (1): 27-51. https://doi.org/10.1353/ nlh.2017.0001.

Vlasov, Sergey, Georgy Zherdev, and Aleksey Dobkin. 2001. V metro (i snaruži). Nablûdeniâ [In the Metro (and Outside). Observations]. Setevaâ slovesnost' [Web Literature], October 30. http://www.netslova.ru/vlasov/metro/index.html.

Open Access This chapter is licensed under the terms of the Creative Commons Attribution 4.0 International License (http://creativecommons.org/licenses/ by/4.0/), which permits use, sharing, adaptation, distribution and reproduction in any medium or format, as long as you give appropriate credit to the original author(s) and the source, provide a link to the Creative Commons licence and indicate if changes were made.

The images or other third party material in this chapter are included in the chapter's Creative Commons licence, unless indicated otherwise in a credit line to the material. If material is not included in the chapter's Creative Commons licence and your intended use is not permitted by statutory regulation or exceeds the permitted use, you will need to obtain permission directly from the copyright holder. 